\title{
Protective Effect of Cranberry Extracts against Oxidative Stress and DNA Damage Induced by Diclofenac Sodium in Kidney of Male Albino Rate
}

\author{
Soha A. Hassan ${ }^{*}$, Dalia A. Sabry ${ }^{2}$, Mohammed A. Hussein ${ }^{3}$ \\ ${ }^{1}$ Department of Basic Sciences, Faculty of dentistry, October 6 University, 6th of October City, Egypt \\ ${ }^{2}$ Zoology Department, Faculty of Science, Mansoura University, Mansoura, Egypt \\ ${ }^{3}$ Department of Biochemistry, Faculty of Applied Medical Sciences, October 6 University, 6th of October City, Egypt \\ Email: *sohaahmed1999@yahoo.com
}

How to cite this paper: Hassan, S.A., Sabry, D.A. and Hussein, M.A. (2017) Protective Effect of Cranberry Extracts against Oxidative Stress and DNA Damage Induced by Diclofenac Sodium in Kidney of Male Albino Rate. Chinese Medicine, 8, 113-131. https://doi.org/10.4236/cm.2017.84009

Received: July 26, 2017

Accepted: December 18, 2017

Published: December 21, 2017

Copyright (๑) 2017 by authors and Scientific Research Publishing Inc. This work is licensed under the Creative Commons Attribution International License (CC BY 4.0).

http://creativecommons.org/licenses/by/4.0/

c) $\underset{\mathrm{EY}}{\text { (7) Open Access }}$

\begin{abstract}
This work aimed to find the effect of cranberry extract (75 and 150 $\mathrm{mg} / \mathrm{kg} \cdot \mathrm{b} \cdot \mathrm{w})$ and vit. C ( $1 \mathrm{~g} / \mathrm{kg} \cdot \mathrm{b} \cdot \mathrm{w}$ orally) on renal toxicity induced by Diclofenac sodium in male albino rats. Treated rats with diclofenac sodium with a concentration $150 \mathrm{mg} / \mathrm{kg} \cdot \mathrm{b} \cdot \mathrm{w}$, expressed a significant increase in several parameters includes, plasma total cholesterol, LDL-cholesterol, and triglyceride as well as renal nitric oxide (NO), tumor necrosis factor-alfa (TNF- $\alpha$ ) and TBARS. In addition, a significant reduction in renal superoxide dismutase (SOD), GSH, catalase (CAT) and plasma HDL. The present results explain that, using cranberry extract and vit. $\mathrm{C}$ resulted in increasing the level of GSH, CAT and SOD as well as gene expression of renal SOD, CAT and IL-22 and reduce the level of TBARs significantly which led to preventing renal tissue damage. Our results also revealed that cranberry extract can protect DNA from damage as obtained from comet essay. TM-U was elevated in DCLF treated group when compared with normal. However cranberry extract was able to reduce this elevation in dose dependant manner. Histological features in $\mathrm{H} \& \mathrm{E}$ taken to different groups also mirrors this findings. DCLF causes many changes in renal tissue include infiltration by inflammatory cells, attenuated glomeruli, apoptosis in tubular epithelia.
\end{abstract}

\section{Keywords}

Diclofenac Sodium, Cranberry, Antioxidant Enzymes, DNA Damage, Renal Cortex 


\section{Introduction}

Nonsteroidal anti-inflammatory drugs (NSAIDs) are commonly used all over the world as a medications [1]. NSAIDs have analgesic, anti-inflammatory and anti-pyretic effects by inhibition of the synthesis of prostaglandin (PG), by suppressing cyclooxygenase (COX) enzyme [2]. Diclofenac may have toxic effects on stomach and kidney, similar to other NSAIDs, by blocking prostaglandin synthesis [3]. Reactive oxygen species are always released through the tissues [4] also they can be deactivated under the effect of (catalase, glutathione peroxidase, superoxide dismutase, etc.) or non-enzymatic (glutathione, vitamin A, vitamin $\mathrm{C}$, etc.) substances [5]. Oxidative and ant-oxidative substances are present in the body in a balance state. If the antioxidants are insufficient or the reactive oxygen radicals are produced extremely, the oxidative stress happens. So, oxidative stress leads to lipid peroxidation. Malondialdehyde (MDA) is the most biological marker used to determine lipid peroxidation [6]. NSAIDs can affect oxidative balance in the body, and some of them have antioxidant activity while others exhibit oxidant activity [3], Craneberry contains about twice the contents of the other usually used fruit juices, as pomegranate and grape [7]. It is the most important source of food plants that contain flavonol, it includes 20 kinds of them [8] [9] and [10]. No reports about antioxidant of cranberry extract against Diclofenac sodium stimulate renal toxicity in rats [11] [12] [13] [14]. The aim of the present study was to explain scavenging of free radical and renal protective activities of cranberry extract and vitamin $\mathrm{C}$ in rat's model of diclofenac sodium-induced renal toxicity.

\section{Materials and Methods}

\subsection{Cranberry Dose}

- Cranberry extract was imported from Virgin Extracts (TM), China. Male rates were treated daily for 21 days by 2 doses of the extract, (75 \& 150 $\mathrm{mg} / \mathrm{kg} \cdot \mathrm{b} \cdot \mathrm{w}$ ) which represent $1 / 150 \& 1 / 75$ of $\mathrm{LD}_{50}$ sequentially. Oral gastric gavage tube was used.

- Diclofenac sodium (100\%) and (Vitamin C, 100\%) were obtained from Merck Ltd., Germany. All used reagents were of analytical grade.

\subsection{Experimental Design}

The present methodology was set up to explain the prophylactic potential of cranberry against Diclofenac sodium induced renal toxicity in-vivo. 50 rats were distributed in 5 groups of animals; 10 rats per each group. Animals were treated daily for 21 days as follows.

- Group I: Normal; was administrated with saline, orally for 21 days.

- Group II: Positive control; was treated with Diclofenac sodium $(150 \mathrm{mg} / \mathrm{mL}$ saline/kg.b.w./day) orally in once daily dose for 21 days [15].

- Group III: was administrated with Cranberry extract $(75 \mathrm{mg} / \mathrm{kg} \cdot \mathrm{b} \cdot \mathrm{w} / \mathrm{mL}$ saline/day, orally) + diclofenac sodium ( $150 \mathrm{mg} / \mathrm{kg} \cdot \mathrm{b} \cdot \mathrm{w} / \mathrm{mL}$ saline/day, orally) 
for 21 days [16].

- Group IV: was treated with Cranberry extract $(150 \mathrm{mg} / \mathrm{kg} \cdot \mathrm{b} \cdot \mathrm{w} / \mathrm{mL}$ saline/day, orally $)+$ diclofenac sodium $(150 \mathrm{mg} / \mathrm{kg} \cdot \mathrm{b} \cdot \mathrm{w} \cdot / \mathrm{mL}$ saline/day, orally $)$ for 21 days [16].

- Group V: was treated with Diclofenac sodium $(150 \mathrm{mg} / \mathrm{kg} \cdot \mathrm{b} \cdot \mathrm{w} / \mathrm{mL}$ saline/day, orally $)+$ Vitamin C ( $1 \mathrm{~g} / \mathrm{kg} \cdot \mathrm{b} \cdot \mathrm{w} / \mathrm{mL}$ saline/day, orally) for 21 days [17].

- The doses of Cranberry extract and vitamin C were given $1 \mathrm{~h}$ before Diclofenac sodium treatment. Blood samples were collected $24 \mathrm{~h}$ after Diclofenac sodium treatment.

\subsection{Biochemical Analysis}

Blood samples: At the end of experimental period, blood samples were obtained in clean, dry, and screw capped tubes, Also, plasma was separated by centrifugation for 15 minutes at $2500 \mathrm{r} \cdot \mathrm{p} \cdot \mathrm{m}$. Separated serum was transformed using automatic pipette into dry sterile tube and placed in a deep freezer at $-20^{\circ} \mathrm{C}$ until used for biochemical analysis.

Renal tissue: Animals were sacrificed by decapitation after 21 days. The rats were dissected for obtaining kidney tissues. The specimens were cleaned by rinsing in ice-cold isotonic saline then dried using filter papers and immediately kept in a deep freezer at $\left(-20^{\circ} \mathrm{C}\right)$ for biochemical analysis of blood and renal GSH [18], superoxide dismutase (SOD) [19], catalase (CAT) [20] and TBARS [21] as well as TNF- $\alpha$ [22] and nitric oxide [23], as well as total protein [24], triglyceride [25], total cholesterol [26], HDL-C [27] and LDL-cholesterol [28]. Finally, renal SOD, CAT and interleukin-22 (IL-22) and Beta actin gene expression were determined depending on the method explained by Pfaffl et al., [29] and Wolk et al., [30].

\subsection{Determination of Renal SOD, CAT and IL-22 Gene Expression}

\section{Primer Design}

Primers were designed according to gene sequence databases of National Center for Biotechnology Information (http://www.ncbi.nlm.nih.gov/). The position of every intron and exon was specified through gene sequences depending on the mRNA sequence for designing the primers at exon-exon junctions to prevent the false positive results. Primers were checked by BLAST (http://blast.ncbi.nlm.nih.gov/Blast.cgi). The primer sequences and appropriate annealing temperatures are shown in the following Table 1 and Table 2.

\subsection{DNA Damage}

$0.5 \mathrm{~g}$ of kidney tissue were crushed and added to $1 \mathrm{ml}$ ice-cold PBS Then, was stirred for $5 \mathrm{~min}$ and filtered. Cell suspension $(100 \mu \mathrm{l})$ was mixed with $600 \mu \mathrm{l}$ of low-melting agarose (0.8\% in PBS). $100 \mu \mathrm{l}$ of the previous mixture was spread on pre-coated slides. The coated slides were submerged in lyses buffer $(0.045 \mathrm{M}$ 
Table 1. Sequence of the SOD and CAT primers used for real-time PCR.

\begin{tabular}{cc}
\hline & \multicolumn{1}{c}{ Primer sequence } \\
\hline \multirow{2}{*}{ SOD } & forward: 5'-GGGGAGGAAGATGTCAAAGC-3, \\
& reverse: 5'-GCCTGAGACCCAATTGAAGG-3' \\
CAT & forward: 5'-CCTGCTGCTGGCCGTAGT-3' \\
& reverse: 5'-GCTGTACGAGGAACACCCCAGCT-3' \\
GAPDH & forward 5'-ATGAGCCCCAGCCTTCTCCAT-3', \\
& reverse: 5'-CCAGCCGAGCCACATCGCTC-3') \\
\hline
\end{tabular}

Table 2. Sequence of the IL-22 primers used for real-time PCR.

\begin{tabular}{cc}
\hline & \multicolumn{1}{c}{ Primer sequence } \\
\hline IL-22 & Forward: 5'-ACAACACAGACGTTCGTCTCATTG-3' \\
& reverse: 5'-GAACAGCACTTCTTCAAGGGTGA-3'5R1 \\
\hline
\end{tabular}

TBE, $\mathrm{pH}$ 8.4, containing 2.5\% SDS) for $15 \mathrm{~min}$. The slides were placed in electrophoresis chamber containing the same TBE buffer, but free of SDS. The conditions of electrophoresis were $2 \mathrm{~V} / \mathrm{cm}$ for $2 \mathrm{~min}$ and $100 \mathrm{~mA}$. Ethidium bromide stain were used $(20 \mu \mathrm{g} / \mathrm{ml})$ at $4^{\circ} \mathrm{C}$. The observed samples were still humid, the DNA fragment migration patterns of 100 cells for each dose level were examined using a fluorescence microscope (With excitation filter 420 - $490 \mathrm{~nm}$ [issue $510 \mathrm{~nm}$ ]). Measurements of comets tails lengths were carried out from the middle of the nucleus till the end of the tail with $40 \times$ increase for the count and measure the size of the comet. Fluorescent microscope ( $40 \times$ objective) was used to visualize the stained DNA damage. We use a Komet 5 image analysis software developed by Kinetic Imaging, Ltd. (Liverpool, UK) linked to a CCD camera to assess the quantitative and qualitative extent of DNA damage in the cells by measuring the length of DNA migration and the percentage of migrated DNA. Finally, the program calculates tail moment. Generally, 50 to 100 randomly selected cells are analyzed per sample.

\subsection{Histological Assessment}

The slices of extracted kidney were fixed in $10 \%$ formaldehyde then, washed to remove fixative and placed in $70 \%$ alcohol followed by ascending series of ethyl alcohol. Tissues were cleared in xylene before embedded in molten paraffin wax $\left(58^{\circ} \mathrm{C}-62^{\circ} \mathrm{C}\right) .5 \mu$ cross sections were cut using microtome and mounted on glass slides. The mounted sections were stained with hematoxylin eosin for light microscopic observation depending on the method of Bancroft and Steven [31].

\subsection{Statistical Analysis}

Statistical differences between the groups were tested by analysis of variance (Anova) using SPSS 15, Inc., Chicago, IL, USA [32]. $P$ value of $>0.05=$ non significant (Ns) $P$ value of $<0.05=$ significant. $P$ value $<0.001=$ highly significant. 


\section{Results}

Table 3 showed that oral administration of Diclofenac sodium at $150 \mathrm{mg}$ leads to a significant elevation in renal TNF- $\alpha$, TBARS and NO versus normal rats $(p$ $<0.01)$. Rat receiving extract of any of the two doses of cranberry extract used in this study (75 and $150 \mathrm{mg}$ ) showed a significant decrease in renal TNF- $\alpha$, NO and TBARS compared to the treated group with Diclofenac sodium $(p<0.01)$. Also, supplementation of vitamin $C$ resulted in a significant decrease in renal TNF- $\alpha$, NO and TBARS versus Diclofenac sodium treated group $(p<0.01)$.

Table 4 and Table 5 showed that administration of Diclofenac sodium produce a significant reduction in the level of blood and renal GSH as well as activities of CAT and SOD compared to the normal control rats $(p<0.01)$. Rat receiving extract of any of the two doses of cranberry extract used in this study (75 and $150 \mathrm{mg}$ ) showed that, the level of renal and blood GSH increased significantly and also the activities of SOD and CAT comparable to Diclofenac sodium treated group $(p<0.01)$. Also, supplementation of vitamin $\mathrm{C}$ leads to a significant elevation in renal and blood GSH as well as activities of CAT and SOD versus to the group treated with Diclofenac sodium $(p<0.01)$.

Table 6 showed that, the level of TG, TC and LDL-C in plasma increased significantly in rat group treated with Diclofenac sodium $(150 \mathrm{mg})$ when compared to the normal control group $(p<0.01)$. Supplementation of cranberry extracts (75 and $150 \mathrm{mg}$ ) leads to a significant reduction in plasma TC, TG and LDL-C compared to the Diclofenac sodium treated group $(p<0.05)$. Also, oral administration of Diclofenac sodium leads to a significant reduction in plasma HDL-C versus normal control group $(p<0.01)$. Administration of cranberry extract (75 and $150 \mathrm{mg}$ ) resulted in a significant increase in plasma HDL-C versus the treated group with Diclofenac sodium $(p<0.01)$.

As shown in Table 7, renal level of IL-22 gene expression in Diclofenac sodium-treated rats was higher compared to the normal control $(P<0.05)$. Treatment with cranberry extract (75 and $150 \mathrm{mg}$ ) resulted in significantly decreased of renal IL-22 gene expression level compared to Diclofenac sodium-treated rats.

Table 3. Level of renal tumor necroses factor- $\alpha$ (TNF- $\alpha$ ), nitric oxide (NO) and thiobarbaturic acid reactive substances (TBARS) different groups.

\begin{tabular}{|c|c|c|c|c|}
\hline No. & Groups & $\begin{array}{l}\text { TNF- } \alpha \\
(\mathrm{Pg} / \mathrm{ml})\end{array}$ & $\begin{array}{c}\mathrm{NO} \\
(\mathrm{Umol} / \mathrm{L})\end{array}$ & $\begin{array}{l}\text { TBARS } \\
\mathrm{nmol} / \mathrm{ml}\end{array}$ \\
\hline (I) & Normal 1\% tween 80 & $22.6 \pm 1.54$ & $16.50 \pm 2.08$ & $10.85 \pm 1.40$ \\
\hline (II) & $\begin{array}{l}\text { Positive control Diclofenac sodium } \\
\qquad(150 \mathrm{mg} / \mathrm{kg} \cdot \mathrm{b} \cdot \mathrm{w})\end{array}$ & $65.87 \pm 5.76^{*}$ & $45.00 \pm 4.27^{*}$ & $23.75 \pm 3.22^{\star}$ \\
\hline (III) & Cranberry extract $(75 \mathrm{mg} / \mathrm{kg} \cdot \mathrm{b} \cdot \mathrm{w})$ & $34.97 \pm 6.77^{*}$ & $26.09 \pm 3.26^{*}$ & $17.60 \pm 2.11^{\star}$ \\
\hline (IV) & Cranberry extract $(150 \mathrm{mg} / \mathrm{kg} \cdot \mathrm{b} \cdot \mathrm{w})$ & $29.80 \pm 1.97^{\star}$ & $20.76 \pm 2.74^{*}$ & $12.70 \pm 3.87^{\star}$ \\
\hline$(\mathrm{V})$ & Vitamin C $(1 \mathrm{~g} / \mathrm{kg} \cdot \mathrm{b} \cdot \mathrm{w})$ & $35.98 \pm 3.25^{\star}$ & $26.59 \pm 2.84^{\star}$ & $14.89 \pm 2.18^{*}$ \\
\hline
\end{tabular}

Values are given as mean \pm SD for 8 rats in each group. ${ }^{*}$ : Significant different from normal group at $p<$ 0.01 . 
Table 4. Level of blood glutathione (GSH) reduction and superoxide dismutase (SOD) and catalase (CAT) activities in different groups.

\begin{tabular}{|c|c|c|c|c|}
\hline No. & Groups & $\begin{array}{c}\mathrm{GSH} \\
(\mathrm{mg} \%)\end{array}$ & $\begin{array}{c}\text { SOD } \\
(\mathrm{U} / \mathrm{gm} \cdot \mathrm{Hb})\end{array}$ & $\begin{array}{c}\text { CAT } \\
(\mathrm{U} / \mathrm{gm} \cdot \mathrm{Hb})\end{array}$ \\
\hline (I) & Normal $1 \%$ tween 80 & $23.64 \pm 2.83$ & $385.54 \pm 18.65$ & $95.22 \pm 5.84$ \\
\hline (II) & $\begin{array}{l}\text { Positive control Diclofenac sodium } \\
\qquad(150 \mathrm{mg} / \mathrm{kg} \cdot \mathrm{b} \cdot \mathrm{w})\end{array}$ & $8.90 \pm 1.77^{\star}$ & $167.25 \pm 9.24^{\star}$ & $48.16 \pm 4.41^{\star}$ \\
\hline (III) & Cranberry extract $(75 \mathrm{mg} / \mathrm{kg} \cdot \mathrm{b} \cdot \mathrm{w})$ & $15.46 \pm 2.17^{\star}$ & $304.42 \pm 11.68^{\star}$ & $73.55 \pm 4.08^{*}$ \\
\hline (IV) & Cranberry extract $(150 \mathrm{mg} / \mathrm{kg} \cdot \mathrm{b} \cdot \mathrm{w})$ & $21.55 \pm 3.06^{*}$ & $389.75 \pm 21.38^{*}$ & $92.20 \pm 4.59^{*}$ \\
\hline (V) & Vitamin C $(1 \mathrm{~g} / \mathrm{kg} \cdot \mathrm{b} \cdot \mathrm{w})$ & $19.80 \pm 2.68^{\star}$ & $360.32 \pm 19.33^{*}$ & $80.05 \pm 6.15^{\star}$ \\
\hline
\end{tabular}

Values are given as mean \pm SD for 8 rats in each group. *: Significant different from normal group at $p<$ 0.01 .

Table 5. Level of renal reduced glutathione (GSH) and superoxide dismutase (SOD) and catalase (CAT) activities in normal and experimental groups of rats.

\begin{tabular}{ccccc}
\hline No. & Groups & $\begin{array}{c}\text { GSH } \\
(\mu \mathrm{g} / \mathrm{mg} \text { of protein })\end{array}$ & $\begin{array}{c}\text { SOD } \\
(\mathrm{U} / \mathrm{mg} \text { protein })\end{array}$ & $\begin{array}{c}\text { CAT } \\
(\mathrm{U} / \mathrm{mg} \text { protein })\end{array}$ \\
\hline (I) & Normal 1\% tween 80 & $11.6 \pm 1.87$ & $15.49 \pm 1.03$ & $21.89 \pm 2.78$ \\
(II) & $\begin{array}{c}\text { Positive control Diclofenac } \\
\text { sodium }(150 \mathrm{mg} / \mathrm{kg} \cdot \mathrm{b} \cdot \mathrm{w})\end{array}$ & $4.37 \pm 0.53^{*}$ & $7.98 \pm 1.24^{*}$ & $9.45 \pm 1.66^{*}$ \\
(III) & $\begin{array}{c}\text { Cranberry extract } \\
(75 \mathrm{mg} / \mathrm{kg} \cdot \mathrm{b} \cdot \mathrm{w})\end{array}$ & $8.09 \pm 1.03^{*}$ & $10.66 \pm 0.87^{*}$ & $16.38 \pm 2.11^{*}$ \\
(IV) & $\begin{array}{c}\text { Cranberry extract } \\
(150 \mathrm{mg} / \mathrm{kg} \cdot \mathrm{b} \cdot \mathrm{w})\end{array}$ & $10.65 \pm 1.23^{*}$ & $14.26 \pm 2.77^{*}$ & $19.70 \pm 3.76^{*}$ \\
(V) & Vitamin C $(1 \mathrm{~g} / \mathrm{kg} \cdot \mathrm{b} \cdot \mathrm{w})$ & $9.80 \pm 0.74^{*}$ & $13.50 \pm 1.74^{*}$ & $15.90 \pm 2.58^{*}$ \\
\hline
\end{tabular}

Values are given as mean $\pm \mathrm{SD}$ for 8 rats in each group. ${ }^{*}$ : Significant different from normal group at $p<$ 0.01 .

Table 6. Plasma Level of total cholesterol (TC), triglycerides (TG), HDL-C and LDL-C in all groups.

\begin{tabular}{cccccc}
\hline No. & Groups & $\begin{array}{c}\text { TC } \\
(\mathrm{mg} / \mathrm{dl})\end{array}$ & $\begin{array}{c}\text { TG } \\
(\mathrm{mg} / \mathrm{dl})\end{array}$ & $\begin{array}{c}\text { HDL-C } \\
(\mathrm{mg} / \mathrm{dl})\end{array}$ & $\begin{array}{c}\text { LDL-C } \\
(\mathrm{mg} / \mathrm{dl})\end{array}$ \\
\hline (I) & $\begin{array}{c}\text { Normal 1\% tween } 80 \\
\text { Positive control }\end{array}$ & $190.54 \pm 9.80$ & $142.66 \pm 8.64$ & $32.17 \pm 3.27$ & $128.84 \pm 13.25$ \\
(II) & $\begin{array}{c}\text { Diclofenac sodium } \\
(150 \mathrm{mg} / \mathrm{kg} \cdot \mathrm{b} \cdot \mathrm{w})\end{array}$ & $248.86 \pm 11.53^{*}$ & $205.23 \pm 13.53^{*}$ & $26.08 \pm 4.05^{*}$ & $181.72 \pm 9.76^{*}$ \\
& $\begin{array}{c}\text { Cranberry extract } \\
(75 \mathrm{mg} / \mathrm{kg} \cdot \mathrm{b} \cdot \mathrm{w})\end{array}$ & $210.43 \pm 16.54^{*}$ & $165.28 \pm 11.87^{*}$ & $30.00 \pm 3.68^{*}$ & $147.38 \pm 11.94^{*}$ \\
(III) & $\begin{array}{c}\text { Cranberry extract } \\
\text { (IV) }\end{array}$ & $195.25 \pm 13.87^{*}$ & $140.94 \pm 9.75^{*}$ & $34.28 \pm 4.11^{*}$ & $132.78 \pm 10.04^{*}$ \\
(V) & Vitamin C $(1 \mathrm{~g} / \mathrm{kg} \cdot \mathrm{b} \cdot \mathrm{w})$ & $215.77 \pm 12.40^{*}$ & $155.18 \pm 11.36^{*}$ & $30.85 \pm 3.07^{*}$ & $153.89 \pm 13.26^{*}$ \\
\hline
\end{tabular}

Values are given as mean $\pm \mathrm{SD}$ for 8 rats in each group. ${ }^{*}$ : Significant different from normal group at $p<$ 0.01. LDL-C $(\mathrm{mg} / \mathrm{dl})=$ TC-HDL-[TG/5].

Also, Table 7 showed that oral administration of Diclofenac sodium (150 mg) leads to a significant reduction in renal SOD and CAT gene expression versus normal control group $(p<0.05)$. Treatment with craneberry extract $(75$ and $150 \mathrm{mg})$ 
Table 7. Effect of Cranberry extract in renal gene expression of SOD, CAT and IL-22 in rats.

\begin{tabular}{ccccc}
\hline No. & Groups & SOD & CAT & IL-22 \\
\hline (I) & Normal 1\% tween 80 & $1.05 \pm 0.14$ & $1.68 \pm 0.24$ & $4.35 \pm 0.34$ \\
(II) & $\begin{array}{c}\text { Positive control Diclofenac } \\
\text { sodium }(150 \mathrm{mg} / \mathrm{kg} \cdot \mathrm{b} \cdot \mathrm{w})\end{array}$ & $0.79 \pm 0.08^{*}$ & $0.93 \pm 0.04^{*}$ & $6.87 \pm 0.53^{*}$ \\
(III) & $\begin{array}{c}\text { Cranberry extract }(75 \mathrm{mg} / \mathrm{kg} \cdot \mathrm{b} \cdot \mathrm{w}) \\
\text { (IV) }\end{array}$ & $0.99 \pm 0.043^{*}$ & $1.27 \pm 0.08^{*}$ & $3.96 \pm 0.06^{*}$ \\
(V) & $\begin{array}{c}\text { Cranberry extract } \\
(150 \mathrm{mg} / \mathrm{kg} \cdot \mathrm{b} \cdot \mathrm{w})\end{array}$ & $0.87 \pm 0.056^{*}$ & $1.54 \pm 0.06^{*}$ & $4.30 \pm 0.08^{*}$ \\
\hline
\end{tabular}

Values are given as mean $\pm \mathrm{SD}$ for 8 rats in each group. ${ }^{*}$ : Significant different from normal group at $p<$ 0.01 .

leads to increasing the level of renal SOD and CAT gene expression significantly compared to Diclofenac sodium treated group $(p<0.05)$.

\subsection{DNA Damage}

Renal cortex cells photomicrographs show different DNA migration patterns when exposed to diclofenac Figure 1. The DNA content migrated as a tails of comet when nuclear DNA damage takes place (Table 8). There is a direct relationship between the degree of damage and the tail length. In Diclofenac sodium treated groups, the level of DNA damage was increased, as represented by the elongation of comet tail. The treatment with cranberry extract efficiently improves the damage, depending on the administrated dose, as appeared by tail length reduction.

T.M-U as marker for DNA fragmentation was markedly higher in diclofenac treated rats $(P<0.0001)$ (Table 8$)$ versus normal control rats. The groups of rats treated with $75 \mathrm{mg}, 150 \mathrm{mg}$ crane berry extracts and $500 \mathrm{mg}$ vit. $\mathrm{C}$ showed that T.M-U highly significant decrease of levels when compared with positive control group (diclofenc groups) of rats $(P<0.0001)$. The treatment effect of $50 \mathrm{mg}$ crane berry extracts was more pronounced than the effect of $75 \mathrm{mg}$ crane berry extracts.

The groups of rats treated with $150 \mathrm{mg}$ crane berry extracts and $500 \mathrm{mg}$ vit. C showed similar T.M-U levels.

\subsection{Histopathological Findings}

Light microscope investigation in control group showed normal histology of renal cortex. Diclofenac sodium diclofenac treated group (group 2) examination revealed many changes in renal tissue include atrophy in renal glomeruli with dilated urinary space. Mild infiltration of inflammatory cell was in between dilated tubules. This group also showed many pyknotic nuclei in renal tubular epithelia appears condensed and heavily stained, other cells in tubular epithelia have pale stained nuclei indicating karyolysis. Vacuolations of the epithelial lining of the tubules are also noticed, group c treated with $75 \mathrm{mg}$ cranberry showed moderate 


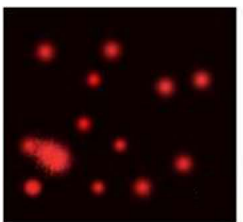

(a)

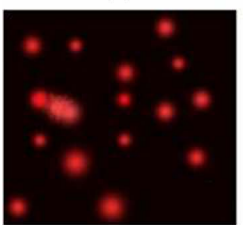

(a)

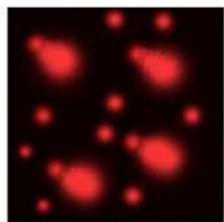

(b)

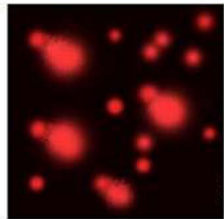

(b)

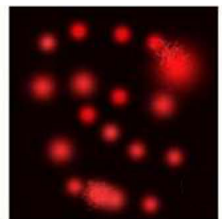

(c)

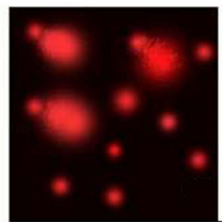

(c)

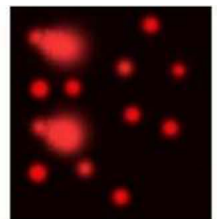

(d)

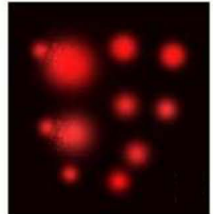

(d)

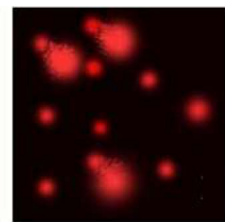

(e)

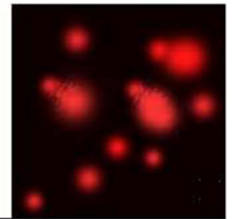

(e)

Figure 1. Photographic pictures of DNA fragment migration patterns by alkaline comet assay evaluated with a fluorescence microscope (a): Control group of rate shows the DNA from single cells looked circular and appeared to be intact; (b): Group treated with Diclofenac sodium diclofenac show tailed nuclei indicating damaged DNA; (c) (d): Rate group treated with cranberry $75 \mathrm{mg}, 150 \mathrm{mg}$ respectively; (e): Vitamin C treated group.

Table 8. Values of mean tail DNA\% (damage), tail length and tail moment of comets. Significant difference is indicated by superscript letters.

\begin{tabular}{cccc}
\hline Group & T. L $\mu \mathrm{m}$ & T.DNA\% & T.M-U \\
\hline A & $1.48 \pm 0.03^{\mathrm{d}}$ & $1.51 \pm 0.06^{\mathrm{e}}$ & $2.24 \pm 0.13^{\mathrm{d}}$ \\
B & $3.67 \pm 0.09^{\mathrm{a}}$ & $3.96 \pm 0.09^{\mathrm{a}}$ & $14.61 \pm 0.67^{\mathrm{a}}$ \\
C & $2.91 \pm 0.04^{\mathrm{b}}$ & $3.50 \pm 0.13^{\mathrm{b}}$ & $10.22 \pm 0.41^{\mathrm{b}}$ \\
D & $2.67 \pm 0.08^{\mathrm{c}}$ & $2.55 \pm 0.07^{\mathrm{d}}$ & $6.84 \pm 0.36^{\mathrm{c}}$ \\
E & $2.63 \pm 0.04^{\mathrm{c}}$ & $2.82 \pm 0.04^{\mathrm{c}}$ & $7.43 \pm 0.18^{\mathrm{c}}$ \\
$P$-VALUE & $<0.0001$ & $<0.0001$ & $<0.0001$ \\
\hline
\end{tabular}

T.M-U as marker for DNA fragmentation was markedly higher in diclofenac treated rats $(P<0.0001)$.

histological change; enlarged urinary space (US), vacolated cytoplasm (V). Group d, Figure 2 \& Figure 3 and E treated with $150 \mathrm{mg}$ cranberry and vitamin C respectively, nearly retained the normal Glomrular $(G)$ shape and epithelial tubular lining with no inflammmatory cells infiltration. Limited changes have been found; pyknotic cells (P) and mild dilation in urinary space (US).

\section{Discussion}

Diclofenac can stimulate huge oxidative stress in vivo as acute renal dysfunction [33] [34]. Medicinal plants are the main source of antioxidant compounds that are comparatively plentiful in human food and may be implicated in protection against cancers, heart and nervous system diseases [35].

The antioxidant function of flavonoid components in craneberry is confirmed [36]. In addition, cranberry procyanidins have been discovered to fight reactive carbonyls by formation of adducts [37], and the present research explained elevation of plasma protein in Diclofenac sodium treated animals. The anti-inflammatory activity of cranberry is due to its proanthocyanidin content [37]. 


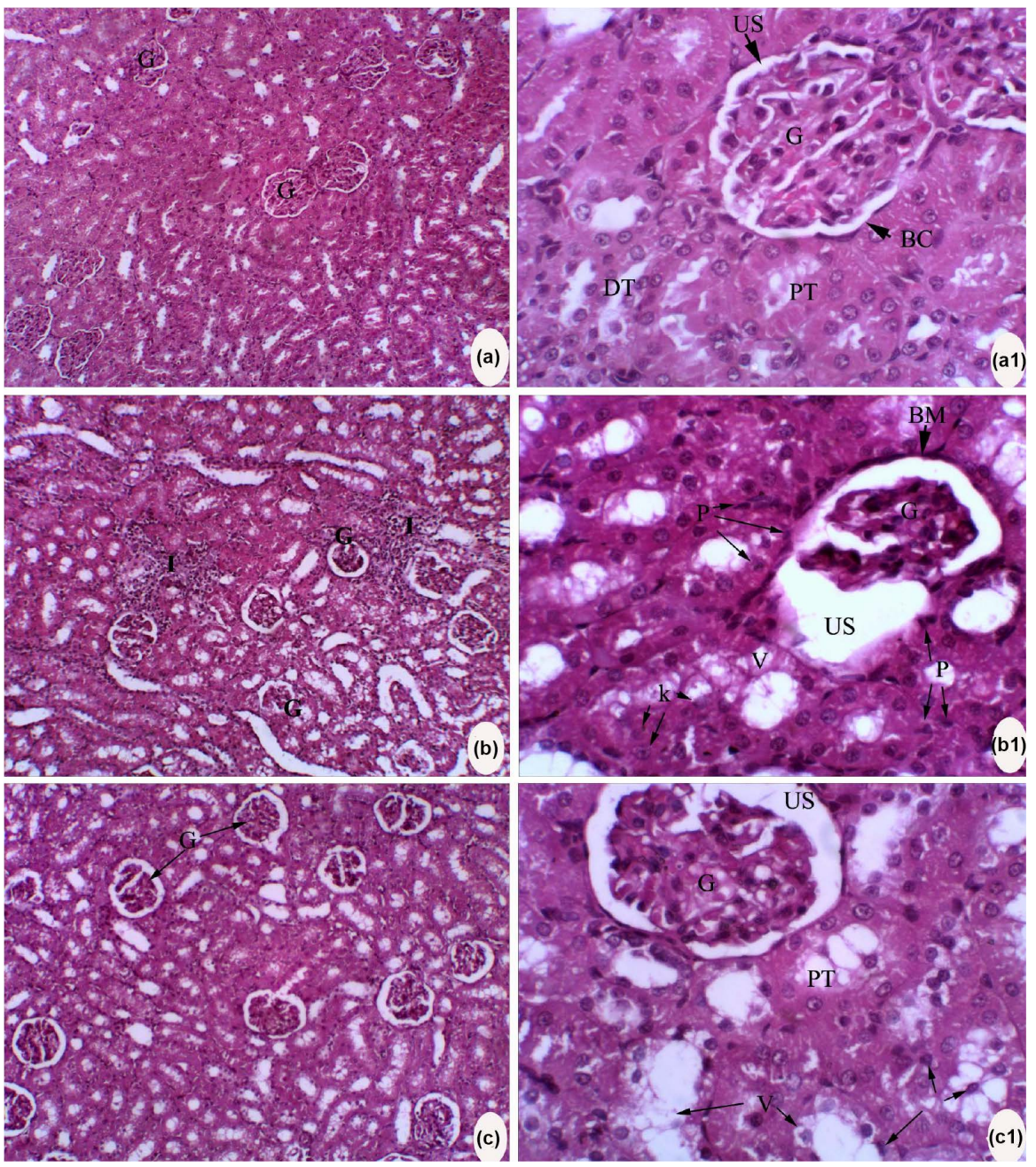

Figure 2. Photomicrograph of a histological section from the renal cortex of adult albino rat stained with (H\&E). (a): Control group showing normal histological architecture; (a1): Higer magnification of previous section show normal appearance of Bowman's capsule (BC) lined with squamous epithelia, glomerulus and urinary space appears normal. Proximal (PT) and distal tubules (DT) have normal epithelial lining; (b): Group of rats treated with Diclofenac sodium diclofenac have mild infiltration (I) of inflammatory cells with abnormal appearance (atrophy) of some glomerulus; (b1): Higher magnification of prev. section show shrunken glomerulus $(G)$ with dilated urinary space (US). Pyknotic nuclei noticed in many cell, thickened basement membrane (BM) lining Bowman's capsule in addition to loss of its uniformly shape, epithelia of renal tubule show vacuolated cytoplasm (v) and karyolysis (K).

The significant increase in level of serum and renal TNF- $\alpha$, NO and TBARS in diclofenac-treated groups indicates ongoing peroxidative stress and compromised antioxidant defense mechanisms. The mechanism of diclofenac-induced mitochondrial injury seems to involve generation of ROS, causing oxidative stress to renal tissue as proposed by Hickey et al. [38]. The underlying mechanisms to produce oxidative stress by the effect of NSAIDs have been suggested to be based on the releasing of NSAID radicals, which in turn can oxidize GSH and $\mathrm{NAD}(\mathrm{P}) \mathrm{H}$. NSAID radicals can undergo redox cycling. In other systems, gastric 


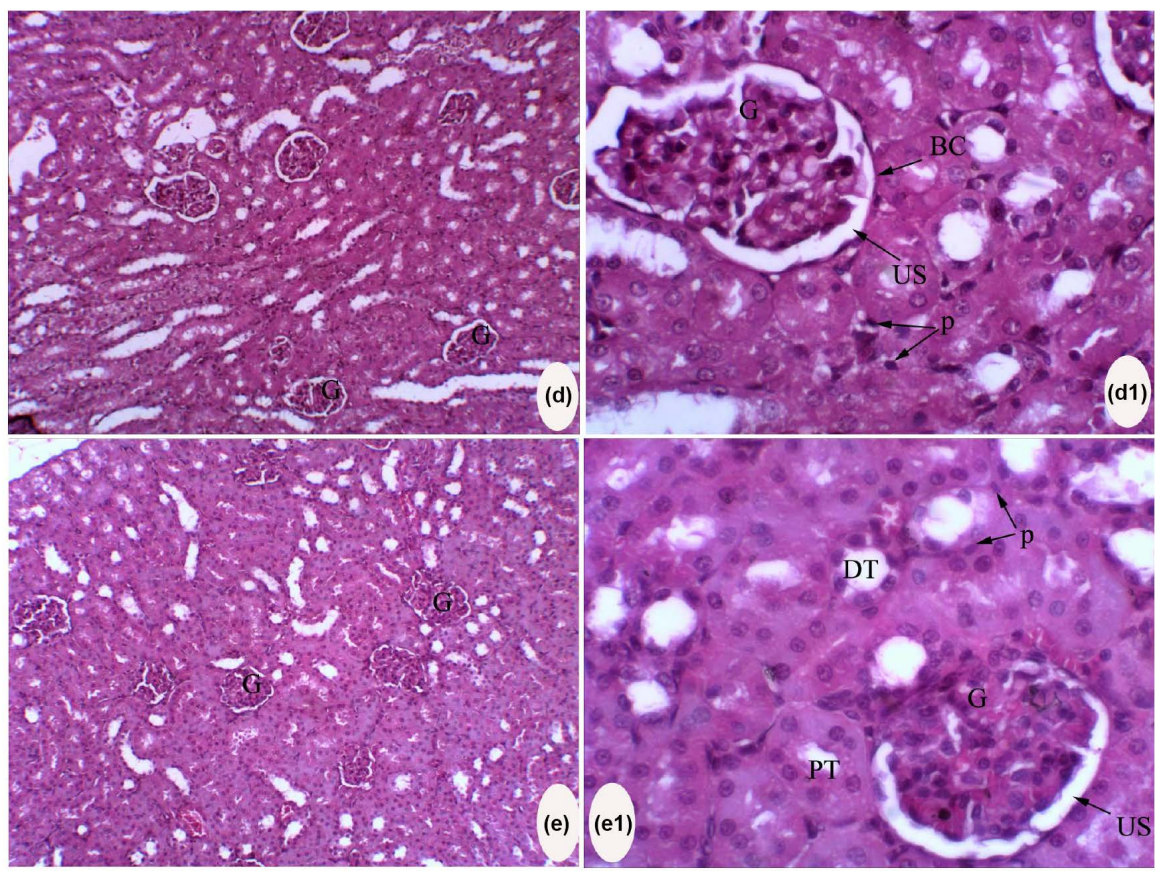

Figure 3. Photomicrograph of histological sections for renal cortex of adult albino rate stained with (H\&E). (d), (d1): Group treated with strong cranberry, (d), (d1): Treated with vitamin $C$ showing renal cortex nearly retained normal size of glomerulus $(G)$, normal squamous cells lining bowman's capsule however widened urinary space (US) is observed and renal tubules still have some pyknotic cells (P).

mucosa lesions is elevated by extracellular TNF- $\alpha$ and NO [39], specially, has been found to give rise to acute cell death in both vitro and vivo [40]. the finding that Diclofenac sodium exposure leads to a fast increase in plasma levels of TNF- $\alpha$ and NO [41] and that suppressing of TNF- $\alpha$ synthesis protects from NSAID-induced gastropathy [42] suggests that this cytokine has an important role in scavenging gastric mucosal injury in NSAID-treated rats. In the present work, NSAIDs activate TNF- $\alpha$ and NO production as well as gene expression of IL-22. It has been demostrated that DIC exposure is incorporated with lipoxygenase-derived peroxides which produce tissue damage [15]. The noticeable elevation in the level of TBARS and HP (lipid peroxidative markers) in the kidney may lead to lipid peroxidation in the DIC-treated animals [16]. Hussein, [12] has mentioned that, the level of lipid peroxides elevated in the tissues of DIC-treated rats. The present work revealed that, TBARS level in kidney was significantly lower in the cranberry and vit. $\mathrm{C}$ treated groups versus the DIC-treated group. Abdel-Maksoud et al., [16] confirmed the present results.

The current study showed a significant decrease in GSH level which refers to the oxidative stress effect of diclofenac in rats renal tissue. Also, there is a reduction in the activity of SOD and CAT and there gene expression in renal tissues of diclofenac treated rats if compared with the normal ones. These results may explain some diclofenac mechanisms to produce toxic effects. The role of GSH, a non-enzymatic antioxidant, is very important in fighting the free radicals re- 
sulted from toxic chemicals and conjugate them to less toxic products [43]. CAT is a widely spread antioxidant enzyme in animal tissues. It protects tissues from hyperactive hydroxyl radicals through decomposing hydrogen peroxide [43]. In diclofenac treated groups, the activity of CAT reduced as well as GSH level through inhibition of its metabolizing enzymes. Thus, the ability of renal tissue to overcome the oxidative stress damage caused by diclofenac is reduced.

The present results agree with other authors who found that, the renal tissues in diclofenac treated animals showed reduction in the levels of enzymatic and non-enzymatic antioxidants [44] [45]. Also, oral administration of Diclofenac sodium leads to significant reduction in renal SOD and CAT gene expression versus normal control group. The present study mainly showing the ameliorating effect of cranberry' polyphenols on Diclofenac induced renal toxicity in studied groups. The decreased concentration of lipid hydroperoxides and thiobarbituric acid reactive substances ensure the ameliorating effect of cranberry polyphenols antioxidant [46]. Diclofenac sodium increases functional abnormalities and cellular damage in renal tissue by the process of lipid peroxidation [12] [38].

The cell membrane contains a large amount of polyunsaturated fatty acids which are susceptible to damage effect of oxidants. This leads to decreasing HDL-C level and increasing LDL-C level [47] [48].

The present work indicate that treatment of rats with diclofenac caused hyperlipidemia which appeared as a significant elevation in lipid profiles (TG, TCh and LDL-C) accompanying with reduction in HDL-C compared to control rats. These results confirmed by the results of Mehta et al. [49].

Hyperlipidemia and elevation of plasma free fatty acids are induced by lipolysis effect of diclofenac sodium [50]. This may be due to its strong inhibitory effect on the synthesis of prostaglandins [51] [52].

Gedik and Collins [53] reported that, oxidative stress is one of the most important factors for increasing DNA damage. Caillet et al. [54] and Skrovankova [55] confirmed that, cranberry has the ability to scavenge the effects of free radical. De Martinis \& Bianchi [56] explained that, the involved frequently attack the DNA resulting in its damage which can be reduced by ingesting food supplement and vitamins combination containing enough amounts of antioxidants. Rahman et al. [57] confirmed that, antioxidants are the most important factors which protect the tissues against activated oxygen species.

Cellular macromolecules including DNA are very susceptible to oxidative injury by ROS, [58]. Other studies indicate that ROS can affect the functional as well as structural integrity of cell membrane and organelles [59] [60]. Apoptosis may be induced by a small amount of oxygen radicals [61] [62]. ROS covalently bind to cellular large molecules including DNA. Single and double strand breaks, and various species of oxidized purines and pyrimidines are evidence that cells have been exposed to oxidative stress [63] [64] [65].

A variety of DNA repair pathways have evolved to protect the DNA [66] [67] 
But according to Hickey et al. [38] DCLF suppress cellular genomic repair capability, and activated kidney endonuclease to produce damage.

The comet assay is an important technique for detecting of DNA damage [68]. The present work showed that the T.M-U was markedly higher in diclofenac treated rats $(P<0.0001)$ if compared with negative control of rats.

These data explained by Pandey et al. [69] who revealed that exposure to diclofenac can cause both DNA and oxidative damages. This may explain apoptotic cell death of kidney tissues [70].

Also, the groups of rats treated with $75 \mathrm{mg}, 150 \mathrm{mg}$ crane berry extracts and $500 \mathrm{mg}$ vit. C showed a highly significant decrease of T.M-U levels when compared with positive control group. The groups of rats treated with $150 \mathrm{mg}$ crane berry extracts and $500 \mathrm{mg}$ vit. C showed similar T.M-U levels. These results confirm the biochemical data in the present study which suggests that cranberry have strong oxygen radical absorbing capacity in a dose dependant manner. So, Cranberry extract is involved in reduce apoptosis and DNA fragmentation.

Many studies reported that SOD2 is the main enzyme of mitochondrial matrix that play an important role in the protection against diclofenac induced-apoptosis and accordingly protect against oxidative stress [71] [72] [73] [74] [75]. SOD2 transfer the toxic superoxide to hydrogen peroxide and molecular oxygen [71].

In this paper the cranberry extract treated group enhances SOD levels and its gene expression. Reduction of apoptosis indicated by results of DNA damage is as well as in his pathological study.

Kidney is a main target for many toxins. NSAD as diclofenac are used clinically. So, it is interesting to study the probable deleterious effects of diclofenac on the kidney tissues [76] [77].

The result of the present study coincided with Abdel Rahm [78] who reported that, the examined normal control kidney stained with haematoxylin and eosin revealed that the renal tubules and corpuscles are the main compartment of the renal cortex. Renal corpuscle composed of glomerulus enclosed by Bowman's capsule. Proximal convoluted tubules had narrower lumen and more eosinophilic cytoplasm than distal convoluted tubules. Both of them are lined with small cuboidal cells.

In the present study, treatment with diclofenac has negative effects on the kidney and could disrupt the normal renal histologic structure. By light microscope, the changes were manifested by the appearance of shrinked glomerulus and inflammatory cells infiltrate in between tubules. Widening of bowman's space and vaculations in the lining epithelium of the tubules were also observed. Similar changes have been recorded by many authors in other experimental models of renal cortex disorders. For instance, in toxic effect of Gibberellic Acid [78], in diclofenac effect on the kidney of the prenatally administered rats [79], and non-Steroidal Anti-Inflammatory drugs as diclofenac, [80] [81] [82], and Meloxicam and Ketoprofen [83].

Samir et al. [84] explained that, treating the body tissues with toxic substances 
leads to activation of the immunity system to react with the produced inflammation. Filiopoulos and Vlassopoulos [85] reported that, appearance of vacuoles in the cellular lining of the renal tubules is the main effect produced as a result cell damage. They explained that, diffusion and accumulation of water inside the cells takes place as a result of increasing the cell membrane permeability. Accordingly, vacuoles are formed.

The recorded histological observations of the present work revealed that inhibition of the diverse effect of diclofenac on the renal cortex is directly proportional with the crane berry concentrations. Such findings go parallel with the observations of Ushijima et al. [86].

The recorded histological observations of the present work revealed that, the treated groups with vit. C and with the higher dose of crane berry extract $(150 \mathrm{~m}$ g) exhibit a weak expression of renal cortex damage; great improvement in the epithelial lining and slight shrinkage of the glomerulus. These results agree with El-shafei and Saleh [87]. Similar findings were reported by Li et al. [88] who studied the effect of vitamin C on DNA damage of mice kidney treated with arsenic.

Jia et al. [89], Konopacka [90] and Sohini \& Rana [91] explained that, vit. C as an antioxidant has the ability to protect the body from nitrogen and reactive oxygen species. Accordingly, it can protect the main biological macromolecules from oxidative stress.

\section{Conclusion}

From the obtained results it could be concluded that cranberry extract was an effective in protection against renal toxicity induced by Diclofenac sodium in rats. Cranberry extract received the highest oxygen radical absorbing capacity (ORAC) value and exhibited superior antioxidant properties and it was able to ameliorate DNA damage and plasma oxidative stress biomarkers as well as enzymatic and non-enzymatic antioxidant defense system in renal tissue.

\section{References}

[1] Gambaro, G. and Perazella, M.A. (2003) Adverse Renal Effects of Anti-Inflam-matory Agents: Evaluation of Selective and Nonselective Cyclooxygenase Inhibitors. Journal of Internal Medicine, 253, 643-652. https://doi.org/10.1046/j.1365-2796.2003.01146.x

[2] Sandhu, G.K. and Heyneman, C.A. (2004) Nephrotoxic Potential of Selective Cyclooxygenase-2 Inhibitors. Annals of Pharmacotherapy, 38, 700-704. https://doi.org/10.1345/aph.1D296

[3] Yapar, K., Atakisi, O., Uzlu, E., Citil, M., Uzun, M., and Erdogan, H.M. (2008) Protective Effect of L Carnitine against Diclofenac Sodium Toxicity in Mice. Revue de Médecine Vétérinaire, 159, 363-367.

[4] Yazar, E. and Tras, B. (2002) Free Oxygen Radicals, Antioxidant Enzymes and Antibiotics. Türk Veteriner Hekimleri Birliği, 14, 42-44.

[5] MAC Donald, J., Gaaley, H. and Webster, N. (2003) Oxidative Stress and Gene Ex- 
pression in Sepsis. British Journal of Anaesthesia, 90, 221-232.

https://doi.org/10.1093/bja/aeg034

[6] Dogan, F. (2011) Pharmacovigilance in Veterinary Profession. Eurasian. Journal of Veterinary Science, 27, 19-25.

[7] Mullen, W., Marks, S.C. and Crozier, A. (2007) Evaluation of Phenolic Compounds in Commercial Fruit Juices and Fruit Drinks. Journal of Agricultural and Food Chemistry, 55, 3148-3157. https://doi.org/10.1021/jf062970x

[8] Aherne, S.A. and O’Brien, M. (2002) Dietary Flavonols: Chemistry, Food Content, and Metabolism. Nutrition, 18, 75-81. https://doi.org/10.1016/S0899-9007(01)00695-5

[9] Vvedenskaya, I.O., Rosen, R.T. and Guido, J.E. (2004) Characterization of Flavonols in Cranberry (Vacciniummacrocarpon) Powder. Journal of Agricultural and Food Chemistry, 52, 188-195. https://doi.org/10.1021/jf034970s

[10] Manach, C., Scalbert, A. and Morand, C. (2004) Polyphenols: Food Sources and Bioavailability. The American Journal of Clinical Nutrition, 79, 727-747.

[11] Hussein, M.A. (2008) Antidiabetic and Antioxidant Activity of Jasonia Montana Extract in Streptozotocin-Induced Diabetic Rats. Saudi Pharmaceutical Journal, 16, 214-221.

[12] Hussein, M.A. (2010) Purslane Extract Effects on Obesity-Induced Diabetic Rats Fed a High-Fat Diet. Malaysian Journal of Nutrition, 3, 419-429.

[13] Hussein, M.A. and Abdelgwad, S.M. (2010) In Vivo Hepato-Protective Properties of Purslane Extracts on Paracetamol-Induced Liver Damage. Malaysian Journal of Nutrition, 1, 161-170.

[14] Hussein, M.A., Abdel-Khalek, N.G. and El Bishbishy, M.H. (2014) Composition, In Vitro Antioxidant and Antitumor Properties of Essential Oil from the Seeds of Moringa Oleifera. International Journal of Pharma Sciences, 3, 532-540.

[15] Boshra, S.A. and Hussein, M.A. (2014) The Protective Role of Colchicine on Diclofenac Sodium Induced Hepato-Renal Toxicity in Albino Rats Model. International Journal of Pharmaceutical Sciences and Research, 12, 5136-5144.

[16] Abdel-Maksoud, H.A., Hussein, M.A. and Barakat, M. (2015) Cranberry Extract as a Functional Food in Treatment of Myocardial Toxicity Induced by Nicotine in Rats. International Journal of Pharma Sciences, 4, 1174-1180.

[17] Luo, Z., Harada, T., London, S., Gajdusek, C. and Mayberg, M. (1995) Antioxidant and Iron Chelating Agents in Cerebral Vasospasm. Neurosurgery, 37, 1054. https://doi.org/10.1227/00006123-199512000-00015

[18] Chanarin, I. (1989) Text Book of Laboratory Haematology: An Account of Laboratory Techniques. Churchill Livingstone, New York, 107.

[19] Marklund, S. and Marklund, D. (1974) Involvement of the Superoxide Anion Radical in the Autoxidation of Pyrogallol and a Convenient Assay for Superoxide Dismutase. European Journal of Biochemistry, 47, 469. https://doi.org/10.1111/j.1432-1033.1974.tb03714.x

[20] Sinha, A.K. (1972) Colorimetric Assay of Catalase. Analytical Biochemistry, 47, 389-394. https://doi.org/10.1016/0003-2697(72)90132-7

[21] Nichans, W.H. and Samulelson, B. (1968) Formation of Malondialdehyde from Phospholipid Arachidonate during Microsomal Lipid Peroxidation. European Journal of Biochemistry, 6, 126-130. https://doi.org/10.1111/j.1432-1033.1968.tb00428.x 
[22] Beyaert, R. and Fiers, W. (1998) Tumor Necrosis Factor and Lymphotoxin. In: Cytokines, A.R.M. and Thorpe, S.A.R., Eds., Academic Press, San Diego, 335-360. https://doi.org/10.1016/B978-012498340-3/50025-7

[23] Miranda, K.M., Espey, M.G. and Wink, D.A. (2001) A Rapid, Simple Spectrophotometric Method for Simultaneous Detection of Nitrate and Nitrite. Nitric Oxide, 5, 62-71. https://doi.org/10.1006/niox.2000.0319

[24] Weichselbaum, T.E. (1946) An Accurate and Rapid Method for the Determination of Proteins in Small Amounts of Blood, Serum and Plasma. American Journal of Clinical Pathology, 16, 40-49.

[25] Fossati, P. and Prencipe, L. (1982) Serum Triacylglycerols Determined Calorimetrically with an Enzyme That Produces Hydrogen Peroxide. Clinical Chemistry, 1, 2077-2080.

[26] Burnstein, M., Selvenick, H.R. and Morfin, R. (1970) Rapid Method for Isolation of Lipoprotein from Human Serum with Polyanions. The Journal of Lipid Research, 11, 583-395.

[27] Allain, C.C., Poon, L.S. and Chan, C.S. (1974) Enzymatic Determination of Total Serum Cholesterol. Clinical Chemistry, 4, 470-475.

[28] Friedewald, W.T. (1972) Estimation of Concentration of Low-Density Lipoprotein Cholesterol in Plasma without Use of the Preparative Ultracentrifuge. Clinical Chemistry, 18, 499-502.

[29] Pfaffl, M., Graham, W. and Leo, D. (2002) Relative Expression Software Tool (REST@) for Group-Wise Comparison and Statistical Analysis of Relative Expression Results in Real-Time PCR. Nucleic Acids Research, 30, e36. https://doi.org/10.1093/nar/30.9.e36

[30] Wolk, K., Kunz, S., Asadullah, K. and Sabat, R. (2002) Cutting Edge: Immune Cells as Sources and Targets of the IL 10 Family Members? The Journal of Immunology, 168, 5397-5402. https://doi.org/10.4049/jimmunol.168.11.5397

[31] Bancroft, G.D. and Steven, A. (1983) Theory and Practice of Histological Technique. 4th Edition, Churchill Livingstone, New York, 99-112.

[32] SPSS (2012) SPSS 15, Inc., Chicago.

[33] Rossi, E., Ferraccioli, G.F., Cavalieri, F., Menta, R., Dall'Aglio, P.P. and Migone, L. (1985) Diclofenac Associated Renal Failure. Nephron, 40, 491-493. https://doi.org/10.1159/000183528

[34] Kim, H., Xu, M., Lin, Y., Cousins, M.J., Eckstein, R.P., Jordan, V., Power, I. and Mather, L.E. (1999) Renal Dysfunction Associated with Perioperative Use of Diclofenac. Anesthesia \& Analgesia, 89, 999-1005.

[35] Teixeira, V., Valente, H. and Casal, S. (2013) Blood Antioxidant and Oxidative Stress Biomarkers Acute Responses to a 1000-m Kayak Sprint in Elite Male Kayakers. The Journal of Sports Medicine and Physical Fitness, 53, 71-79.

[36] Côté, J., Caillet, S., Doyon, G., Sylvain, J.F. and Lacroix, M. (2010) Bioactive Compounds in Cranberries and Their Biological Properties. Critical Reviews in Food Science and Nutrition, 50, 666-679. https://doi.org/10.1080/10408390903044107

[37] Howell, A.B., Leahy, M., Kurosawa, E. and Guthrie, N. (2001) In Vivo Evidence That Cranberry Proanthocyanidins Inhibit Adherence of p-Fimbriated E. coli Bacteria to Uroepithelial Cells. Federation of American Societies for Experimental Biology Journal, 15, A284.

[38] Hickey, E.J., Raje, R.R., Reid, V.E., Gross, S.M. and Ray, S.D. (2001) Diclofenac Induced in Vivo Nephrotoxicity May Involve Oxidative Stress-Mediated Massive Ge- 
nomic DNA Fragmentation and Apoptotic Cell. Free Radical Biology \& Medicine, 31, 139-152.

[39] Eissner, G., Flohlhuber, F. and Grell, M. (1995) Critical Involvement of Transmembrane Tumor Necrosis Factor in Endothelial Programmed Cell Death Mediated by Ionizing Radiation and Bacterial Endotoxin. Blood, 86, A4184.

[40] Salvesen, G.S. and Dixit, V.M. (1997) Caspases: Intracellular Signaling by Proteolysis. Cell, 91, 443-446. https://doi.org/10.1016/S0092-8674(00)80430-4

[41] Appleyard, C.B., McCafferty, D.-M., Tigle, A.W., Swain, G. and Wallace, J.L. (1996) Tumor Necrosis Factor Mediation of NSAID-Induced Gastric Damage: Role of leuKocyte Adherence. American Journal of Physiology, 270, G42-G48.

[42] Fiorucci, S., Santucci, L. and Gerli, R. (1997) NSAIDs Upregulate $\beta_{2}$-Integrin Expression on Human Neutrophils through a Calcium-Dependent Pathway. Alimentary Pharmacology \& Therapeutics, 11, 671-680. https://doi.org/10.1046/j.1365-2036.1997.00190.x

[43] Ding, G. (2012) Cardioprotection from Oxidative Stress in the Newborn Heart by Activation of PPAR $\gamma$ Is Mediated by Catalase. Free Radical Biology \& Medicine, 53, 208-215. https://doi.org/10.1016/j.freeradbiomed.2012.05.014

[44] Baravalia, Y., Vaghasiya, Y. and Chanda, S. (2011) Hepatoprotective Effect of Woodfordia fruticosa Kurz Flowers on Diclofenac Sodium Induced Liver Toxicity in Rats. Asian Pacific Journal of Tropical Medicine, 4, 342-346. https://doi.org/10.1016/S1995-7645(11)60100-4

[45] Sies, H. (1997) Oxidative Stress, Oxidants and Antioxidants. Experimental Physiology, 82, 291-295. https://doi.org/10.1113/expphysiol.1997.sp004024

[46] Veerappan, R.M., Senthil, S., Rao, M. and Ravikumar, M. (2004) Redox Status and Lipid Peroxidation in Alcoholic Hypertensive Patients and Alcoholic Hypertensive Patients with Diabetes. Clinica Chimica Acta, 340, 207-212. https://doi.org/10.1016/j.cccn.2003.11.004

[47] Britton, R.S., Bacon, B.R. and Recknagel, R.O. (1987) Lipid Peroxidation and Associated Hepatic Organelle Dysfunction in Iron Overload. Chemistry and Physics of Lipids, 45, 207-239. https://doi.org/10.1016/0009-3084(87)90066-1

[48] Brunet, S., Thibault, L., Delvin, E., Yotov, W., Bendayan, M. and Levy, E. (1999) Dietary Iron Overload and Induced Lipid Peroxidation Are Associated with Impaired Plasma Lipid Transport and Hepatic Sterol Metabolism in Rats. Hepatology, 29, 1809-1817. https://doi.org/10.1002/hep.510290612

[49] Mehta, R., Shang, A. and O’brien, P.J. (2008) Preventing Cell Death Induced by Carbonyl Stress, Oxidative Stress or Mitochondrial Toxins with Vitamin B Anti-AGE Agents. Molecular Nutrition \& Food Research, 52, 379-385. https://doi.org/10.1002/mnfr.200600190

[50] Abdel Aziz, I.S. (2001) Effect of Indomethacin Suppository on Serum Glucose, Some Lipids, Non-Protein Nitrogen Constituents and Rectal Mucosa of Rabbit. An-Najah University Journal for Research, 15, 1-14.

[51] Zanaboni, L. and Fasoli, A. (1981) Influence of Two Nonsteroidal Anti-Inflammatory Drugs on Lipolysis and on Lipolysis and on Plasma Post-Heparin Lipoprotein Lipase Activity in Normal Man. European Journal of Clinical Pharmacology, 20, 263-267. https://doi.org/10.1007/BF00618776

[52] Axelrod, L. (1992) Coordinate Control of Lipolysis by Prostaglandin E2 and Prostacyclin in Rat Adipose Tissue. Diabetes, 41, 927-935.

https://doi.org/10.2337/diab.41.8.927 
[53] Gedik, C. and Collins, A. (2005) ESCODD (European Standards Committee on Oxidative (DNA Damage) Establishing the Background Level of Base Oxidation in Human Lymphocyte DNA: Results of an Interlaboratory Validation Study. FASEB Journal, 19, 82-84.

[54] Caillet, S., Côté, J., Doyon, G., Sylvain, J.-F. and Lacroix, M. (2011) Antioxidant and Antiradical Properties of Cranberry Juice and Extracts. Food Research International, 44, 1408-1413. https://doi.org/10.1016/j.foodres.2011.02.019

[55] Skrovankova, S., Sumczynski, D., Mlcek, J., Jurikova, T. and Sochor, J. (2015) Bioactive Compounds and Antioxidant Activity in Different Types of Berries. International Journal of Molecular Sciences, 16, 24673-24706. https://doi.org/10.3390/ijms161024673

[56] De Martinis, B.S. and Bianchi, M.D. (2001) Effect of Vitamin C Supplementation against Cisplatin-Induced Toxicity and Oxidative DNA Damage in Rats. Pharmacological Research, 44, 317-320. https://doi.org/10.1006/phrs.2001.0860

[57] Rahman, T., Hosen, I., Towhidul Islam, M.M. and Uddin Shekhar, H. (2012) Oxidative Stress and Human Health. Advances in Bioscience and Biotechnology, 3, 997-1019. https://doi.org/10.4236/abb.2012.327123

[58] Ray, S.D., Kumar, A. and Bagchi, D. (1999) A Novel Proanthocyanidin IH636 Extract Increases in Vivo bcl-XL Expression and Prevents Acetaminophen-Induced Programmed and Unprogrammed Cell Death in Mouse Liver. Archives of Biochemistry and Biophysics, 369, 42-58. https://doi.org/10.1006/abbi.1999.1333

[59] Aydin, G., Gokcimen, A., Oncu, M., Cicek, E., Karahan, N. and Gokalp, O. ( 2003) Histopathologic Changes in Liver and Renal Tissues Induced by Different Doses of Diclofenac Sodium in Rats. Turkish Journal of Veterinary and Animal Sciences, 27, 1131-1140.

[60] Khan, M.R. and Ahmed, D. (2009) Protective Effects of Digera muricata (L.) Mart. on Testis against Oxidative Stress of Carbon Tetrachloride in Rat. Food and Chemical Toxicology, 2, 1393-1399. https://doi.org/10.1016/j.fct.2009.03.020

[61] Beyer, W.F. and Fridovich, I. (1991) Phosphate, Not Superoxide Dismutase, Facilitates Electron Transfer from Ferrous Salts to Cytochrome c. Archives of Biochemistry and Biophysics, 285, 60-63. https://doi.org/10.1016/0003-9861(91)90328-G

[62] Finkel, T. and Holbrook, N.J. (2000) Oxidants, Oxidative Stress and the Biology of Aging. Nature, 408, 239-247. https://doi.org/10.1038/35041687

[63] Sanchez-Jimenez, F. (1999) Antioxidant Enzymes and Their Implications in Pathophysiologic Processes. Frontiers in Bioscience, 4, 339-345. https://doi.org/10.2741/A432

[64] Singh, N.P., Danner, D.B., Tice, R.R., Brant, L. and Schneider, E.L. (1990) DNA Damage and Repair with Age in Individual Human. Mutation Research, 237, 123-130. https://doi.org/10.1016/0921-8734(90)90018-M

[65] Singh, N.P., Graham, M.M., Singh, V. and Khan, A. (1995) Induction of DNA Single-Strand Breaks in Human Lymphocytes by Low Doses of X-Rays. International Journal of Radiation Biology, 68, 563-569. https://doi.org/10.1080/09553009514551551

[66] Saville, J. and Fadok, V. (2000) Corpse Clearance Defines the Meaning of Cell Death. Nature, 407, 784-788. https://doi.org/10.1038/35037722

[67] Ray, S.D. and Jena, N. (2000) A Hepatotoxic Dose of Acetaminophen Modulates Expression of bcl-2, bcl-XL, and bcl-Xs during Apoptotic and Necrotic Death of Mouse Liver Cells in Vivo. Archives of Toxicology, 73, 594-606. https://doi.org/10.1007/s002040050013 
[68] Moffitt, T., Hariton, F., Devlin, M., Garrett, P.J. and Hannon, M.P.A. (2014) Oxidative DNA Damage Is Elevated in Renal Patients Undergoing Haemodialysis. Open.

[69] Pandey, P.K., Ajima, M.N.O., Kumar, K., Poojary, N. and Kumar, S. (20017) Evaluation of DNA Damage and Physiological Responses in Nile Tilapia, Oreochromis niloticus (Linnaeus, 1758) Exposed to Sub-Lethal Diclofenac (DCF). Aquatic Toxicology, 186, 205-214. https://doi.org/10.1016/j.aquatox.2017.03.007

[70] Hur, E., Duman, E., Bozkurt, D., Sozmen, E., Sen, S., Taskin, H., Timur, O., Kaya, S.O. and Duman, S. (2012) Non Steroidal Anti-Inflammatory Drugs May Be Harmful to Normal Kidneys: Experimental Surgery Model. Hippokratia, 16, 160-165.

[71] Francesca, C., Annarita, I., Francesco, A., Claudia, Z, Immacolata, C., Pasquale, G., Mariorosario, M. and Maria, R.R. (2010) Diclofenac-Induced Apoptosis in the Neuroblastoma Cell Line SH-SY5Y: Possible Involvement of the Mitochondrial Superoxide Dismutase. Journal of Biomedicine and Biotechnology, 2010, Article ID: 801726.

[72] Li, C., Wright, M.M. and Jackson, R.M. (2002) Reactive Species Mediated Injury of Human Lung Epithelial Cells after Hypoxiareoxygenation. Experimental Lung Research, 28, 373-389. https://doi.org/10.1080/01902140290092001

[73] Pani, G., Bedogni, B., Anzevino, R., et al. (2000) Deregulated Manganese Superoxide Dismutase Expression and Resistance to Oxidative Injury in p53-Deficient Cells. Cancer Research, 60, 4654-4660.

[74] Tanaka, H., Matsumura, I., Ezoe, S., et al. (2002) E2F1 and c-Myc Potentiate Apoptosis through Inhibition of NF- $\kappa$ B Activity That Facilitates MnSOD-Mediated ROS Elimination. Molecular Cell, 9, 1017-1029. https://doi.org/10.1016/S1097-2765(02)00522-1

[75] Kokoszka, J.E., Coskun, P., Esposito, L.A. and Wallace, D.C. (2001) Increased Mitochondrial Oxidative Stress in the Sod2 (+/-) Mouse Results in the Age-Related Decline of Mitochondrial Function Culminating in Increased Apoptosis. Proceedings of the National Academy of Sciences of the United States of America, 98, 2278-2283. https://doi.org/10.1073/pnas.051627098

[76] El-Kordy, E.A. and Makhlouf, M.M. (2014) Possible Protective Role of Ginger Extract on Diclofenac Induced Hepatotoxicity in Adult Male Albino Rats (Histological and Ultrastructural Studies). Life Science Journal, 11, 248-258.

[77] El-Maddawy, Z. and El-Ashmawy, I.M. (2013) Hepato-Renal and Hematological Effects of Diclofenac Sodium in Rats. Global Journal of Pharmacology, 7, 123-132.

[78] Abdel Rahm, M.A., Abdel Atty, Y.H., Abdul Rahman, M.M. and Sabry, M. (2017) Structural Changes Induced by Gibberellic Acid in the Renal Cortex of Adult Male Albino Rats. MOJ Anatomy \& Physiology, 3, Article ID: 00080.

[79] Khoshvakhti, H., Yurt, K.K., Altunkaynak, B.Z., Türkmen, A.P., Elibol, E., Aydın, I., Kivrak, E.G., Önger, M.E. and Kaplan, S. (2015) Effects of Melatonin on Diclofenac Sodium Treated Rat Kidney: A Stereological and Histopathological Study. Renal Failure, 37, 1379-1383. https://doi.org/10.3109/0886022X.2015.1073556

[80] Khoshvakhti, H., Yurt, K.K., Altunkaynak, B.Z., Turkmen, A.P., Elibol, E., Aydın, I., Kivrak, E.G., Onger, M.E. and Kaplan, S. (2015) Effects of Melatonin on Diclofenac Sodium Treated Rat Kidney: A Stereological and Histopathological Study. Renal Failure, 37, 1379-1383. https://doi.org/10.3109/0886022X.2015.1073556

[81] Hasan Mohammed, A.A. (2015) Toxic and Histopathological Changes of Harmful Effect of Diclofenac Sodium on Some Loose Organs in Albino Rats for Twelve Weeks. JMSCR, 3, 4694-4702. 
[82] Yasmeen, T., Qureshi, G.S. and Perveen, S. (2007) Adverse Effects of Diclofenac Sodium on Renal Parenchyma of Adult Albino Rats. The Journal of the Pakistan Medical Association, 57, 349-351.

[83] Mahmoud, F.Y., Abou-Elghait, A.T., Rateb, A. and Salah, E. (2010) Comparative Study on the Effect of Long-Term Administration of Non-Steroidal Anti-Inflammatory Drugs Meloxicam and Ketoprofen on the Structure of the Kidney and Gastric Mucosa in the Adult Albino Rats. Egyptian Journal of Histology, 33, 722-734.

[84] Samir, A.N., Fawzya, A., Ahmed, M.H., Mohamed, N.M. and Asmaa, S.H. (2012) Cytogenetic, Histological and Histochemical Studies on the Effect of Gibberellin A3 in Albino Rats. Journal of American Science, 8, 75-83.

[85] Filiopoulos, V. and Vlassopoulos, D. (2009) Inflammatory Syndrome in Chronic Kidney Disease: Pathogenesis and Influence on Outcomes. Inflammation \& Allergy Drug Targets, 8, 369-382. https://doi.org/10.2174/1871528110908050369

[86] Ushijima, K., Tsuruoka, S., Tsuda, H., Hasegawa, G., Obi, Y., Kaneda, T., Takahashi, M., Maekawa, T., Sasaki, T., Koshimizu, T. and Fujimura, A. (2009) Cranberry Juice Suppressed the Diclofenac Metabolism by Human Liver Microsomes, But Not in Healthy Human Subjects. BJCP, 68, 194-200. https://doi.org/10.1111/j.1365-2125.2009.03436.x

[87] El-shafei, R.A. and Saleh, R.M. (2016) Pharmacological Effects of Vitamin C \& E on Diclofenac Sodium Intoxicated Rats. Biomedicine and Pharmacotherapy, 84, 314-322. https://doi.org/10.1016/j.biopha.2016.09.005

[88] Li, Z., Piao, F., Liu, S., Shen, L., Sun, N., Li, B. and Qu, S. (2009) Prevention Effect of Taurine and Vitamin C of Renal DNA Damage of Mice Exposed to Arsenic. Journal of Occupational Health, 51, 169-172. https://doi.org/10.1539/joh.L8038

[89] Jia, L., Jia, Q., Shang, Y., Dong, X. and Li, L. (2015) Vitamin C Intake and Risk of Renal Cell Carcinoma: A Meta-Analysis. Scientific Reports, 5, Article No. 17921.

[90] Konopacka, M. (2004) Role of Vitamin C in Oxidative DNA Damage. Postepy Higieny I Medycyny Doswiadczalnej, 58, 343-348.

[91] Sohini, R.S.V. (2007) Amelioration of Arsenic Toxicity L-Ascorbic Acid in Laboratory Rat. Journal of Environmental Biology, 28, 377-384. 